\title{
PERSEPSI MAHASISWA TERHADAP KECERDASAN EMOSIONAL SETELAH DITERAPKAN TEKNIK COLLABORATIVE WRITING
}

\author{
Eka Fajar Rahmani \\ Pendidikan Bahasa Inggris, Universitas Tanjungpura \\ Jalan Prof. Hadari Nawawi, Pontianak Tenggara, Pontianak, Kalimantan Barat \\ e-mail: ekasastria10@fkip.untan.ac.id
}

\begin{tabular}{cccc}
\hline Submitted & Accepted & Published \\
$2021-01-22$ & $2021-05-17$ & $2021-05-20$ & OPEN \\
\hline
\end{tabular}

\begin{abstract}
Abstrak
Penelitian bertujuan untuk mengetahui apakah penerapan teknik collaborative writing dapat mengembangkan kecerdasan emosional mahasiswa. Penelitian menggunakan metode deskriptif kuantitatif. Alat pengumpul data menggunakan kuesioner berdasarkan pada 5 aspek kecerdasan emosional yang mencakup selfawareness, self-regulation, self-motivation, social awareness, dan social skills. Teknik analisis data dilakukan dengan perhitungan persentase dari butir kuesioner, dilanjutkan dengan interpretasi dan deskripsi data dari persepsi mahasiswa terhadap kecerdasan emosional setelah teknik collaborative writing diterapkan. Subjek penelitian adalah mahasiswa Sekolah Tinggi Bahasa Asing Pontianak yang mengikuti kelas Essay Writing dan Literary Criticism berjumlah 43 orang dan dipilih menggunakan teknik purposive sampling. Berdasarkan hasil analisis data, terjadi peningkatan kecerdasan emosional mahasiswa setelah diterapkannya teknik collaborative writing yang ditunjukkan dengan peningkatan respons pada aspek kecerdasan emosional.
\end{abstract}

Kata Kunci: teknik collaborative writing; kecerdasan emosional; mahasiswa Bahasa Inggris.

\begin{abstract}
This research aimed to find out if the implementation of collaborative writing techniques could develop the emotional intelligence of students. This research used descriptive quantitative method. Data collection tools used a questionnaire based on 5 aspects of emotional intelligence which include self-awareness, self-regulation, self-motivation, social awareness, and social skills. The data were analyzed by calculating the percentages of each questionnaire item, then continued to interpret and describe the implementation of collaborative writing technique. The subjects of this research were 43 students of Sekolah Tinggi Bahasa Asing Pontianak who enrolled in Essay Writing and Literary Criticism classes, with a total of 43 students who were selected using purposive sampling technique. The results of the data analysis indicated that there happened improvements towards the emotional intelligence after collaborative technique was implemented shown by the increase of positive responses on emotional intelligence aspects.
\end{abstract}

Keywords: collaborative writing technique; emotional intelligence; English language students. 


\section{PENDAHULUAN}

Pembelajaran kolaboratif (collaborative learning) bukanlah hal baru di dunia pendidikan. Pendekatan kolaboratif sudah sering dibahas oleh para peneliti dan praktisi pendidikan karena keefektifan dan keefisiensiannya dalam meningkatkan kemampuan peserta didik, baik secara akademik maupun sosial (Junus \& Andula, 2020; Sunita et al., 2020; Le et al., 2018; Nisa et al., 2018). Secara definisi, pembelajaran kolaboratif adalah sebuah proses dimana peserta didik berinteraksi dalam kelompok kecil beranggotakan tidak lebih dari 6 orang dengan tujuan untuk meminta dan menghormati kemampuan serta kontribusi masing-masing anggota grup (Bol \& Hacker, 2012). Pada penerapannya, selama proses pembelajaran, peserta didik didorong untuk mengawasi performanya, baik dalam interaksi antaranggota kelompok dalam grup, maupun dalam pengingkatan pemahaman materi yang didiskusikan (Le et al., 2018; Wicaksono, 2013). Hal tersebut sangat disarankan karena peserta didik akan dapat menstimulasi diri untuk mengembangkan perspektif kognitif, psikomotor, dan afektif yang sangat bermanfaat untuk memperluas perspektif dalam belajar (Ibrahim et al., 2015; Husain, 2013; Wicaksono, 2013).

Pembelajaran kolaboratif sangat disarankan pada mata pelajaran Bahasa Inggris, khususnya pada keterampilan menulis (writing skill). Bahkan, pembelajaran kolaboratif pada keterampilan menulis memiliki sebuah teknik tersendiri yang disebut collaborative writing $(\mathrm{CW})$ technique. Teknik $\mathrm{CW}$ adalah bagian dari pembelajaran kolaboratif yang mengharuskan peserta didik untuk berkolaborasi (bekerja sama) dalam menghasilkan sebuah hasil karya tulisan (Zhang, 2018). Teknik CW memerlukan keterlibatan timbal balik antarpeserta didik dalam kelompok, interaksi/kerja sama berkelanjutan, proses pengambilan keputusan bersama, dan berbagi tanggung jawab untuk menyelesaikan tugas (McDonough, et al. dalam Zhang, 2018). Teknik CW merupakan teknik pembelajaran yang lebih potensial dalam melibatkan peserta didik untuk belajar secara aktif dengan memanfaatkan sumber daya yang ada pada peserta didik, seperti ide, pemikiran kritis dalam bertanya, pengajaran dengan rekan, dan pengetahuan tentang berbagai topik. Dengan kata lain, teknik CW memungkinkan 
Edukasi: Jurnal Pendidikan, Volume 19 Nomor 1 Tahun 2021

Persepsi Mahasiswa terhadap Kecerdasan Emosional.......

Eka Fajar Rahmani

Halaman 135-149

peserta didik bekerja sama dengan tujuan berbagi ide atau melakukan peerteaching untuk menghasilkan karya tulis yang kaya (Talib \& Cheung, 2017).

Teknik CW memberikan keuntungan bagi peserta didik, khususnya dalam menciptakan pengalaman berharga ketika bekerja sebagai tim untuk mencapai tujuan bersama dan mendapatkan kepuasan dengan berkontribusi pada kinerja (Deveci, 2018; Le et al., 2018; Talib \& Cheung, 2017; Fong, 2012). Teknik CW memungkinkan peserta didik untuk memikul tanggung jawab sendiri dalam belajar, menumbuhkan kedewasaan dalam menemukan gaya belajar, mengembangkan pemikiran kritis kapan menyusun tulisan sendiri, dan juga membangun keterampilan sosial (Deveci, 2018). Melalui proses menulis secara kolaboratif, peserta didik akan mengembangkan ide-ide tulisan, mengulas, serta mengutip pendapat dengan lebih baik (Rahayu, 2016).

Serangkaian kegiatan kolaboratif yang dilakukan pada saat teknik CW diterapkan merujuk pada 5 domain atau aspek kecerdasan emosional yang meliputi knowing one's emotion (self-awareness), managing emotions (self-regulation), motivating oneself (self-motivation), recognizing emotion in others (social awareness), dan handing relationship (social skills) yang saling mendukung satu dengan lainnya (scaffolding) (Serrat, 2017). Kecerdasan emosional sendiri pertama kali diperkenalkan oleh Peter Salovey dan John Mayer pada tahun 1990 sebagai salah satu konsep dari jenis kecerdasan yang merujuk pada konsep kecerdasan sosial dari E. L. Thorndike tahun 1920 dan konsep kecerdasan ganda dari Gardner tahun 1983 (Luy-Montejo, 2019). Kecerdasan emosional diartikan sebagai kemampuan untuk mengerti emosi, menggunakan/memanfaatkan emosi untuk membantu pikiran, mengenal emosi/pengetahuan emosi, dan mengarahkan emosi secara reflektif sehingga menuju pada pengembangan emosi (Luy-Montejo, 2019; Romero-Ternero, 2013; Yahaya et al., 2012).

Kecerdasan emosional mendeskripsikan kemampuan, kapasitas, keterampilan/kemampuan self-perceived untuk mengidentifikasi, menilai, dan mengelola emosi terhadap diri sendiri, orang lain, dan kelompok agar menjadi lebih produktif dan sukses atas apa yang dikerjakan (Serrat, 2017). Proses dan hasil pengembangan kecerdasan emosional memiliki elemen yang dapat mengurangi 
tingkat stres karena kecerdasan emosional memoderasi konflik, meningkatkan pemahaman akan hubungan, serta memupuk stabilitas, kontinuitas, dan harmonisme (Goleman, 1996). Hasil penelitian-penelitian terdahulu menunjukkan bahwa teknik CW secara efektif mampu mengembangkan kemampuan menulis (academic aspect) dan juga soft skills subjek penelitian, seperti kemampuan berinteraksi, open-mindedness, empati, dan bernegosiasi (Deveci, 2018; Talib \& Cheung, 2017). Kegiatan kolaborasi yang dilakukan oleh peserta didik dapat meningkatkan positive ambience yang memicu diri peserta didik untuk mengembangkan emosi positif yang menjadi kecerdasan emosional (Emmanuel et al., 2016; Romero-Ternero, 2013).

Berdasarkan hasil praobservasi yang dilakukan, peneliti menemukan sebuah masalah yang berkaitan dengan kecerdasan emosional pada subjek penelitian. Peneliti menemukan adanya indikasi egosentrisme pada mahasiswa dimana mahasiswa tidak dapat bekerja dalam grup dengan baik dan lebih senang bekerja secara individu. Hal tersebut berakibat pada harmonisme, interaksi, dan lingkungan kelas yang positif tidak tampak pada kelas tersebut. Setelah melakukan wawancara kepada beberapa subjek penelitian, peneliti menemukan pemicu utama terjadinya permasalahan, yaitu adanya rasa kurang percaya terhadap orang lain dan tidak percaya diri untuk dapat berbaur dengan yang lain. Jika ditelaah lebih dalam, kedua pemicu dapat berdampak negatif pada aspek-aspek kecerdasan emosional terutama pada aspek social skills, self-motivation, dan social awareness yang seharusnya dapat berkembang dengan sangat baik pada mahasiswa. Konsekuensinya, jika kecerdasan emosional tidak berkembang, mahasiswa akan menghadapi hambatan untuk menjadi sukses; karena seperti yang diketahui bersama bahwa kecerdasan emosional lebih menentukan kesuksesan seseorang dibandingkan dengan kecerdasan atau akademik.

Berdasarkan pada permasalahan yang telah diuraikan serta hasil penelitian sebelumnya tentang kecerdasan emosional dan teknik kolaborasi, peneliti melakukan penelitian yang dapat membantu mahasiswa mengembangkan kecerdasan emosional melalui teknik pembelajaran kolaboratif, khususnya teknik CW. Dengan menggabungkan konsep kecerdasan emosional dan teknik CW, 
Edukasi: Jurnal Pendidikan, Volume 19 Nomor 1 Tahun 2021

Persepsi Mahasiswa terhadap Kecerdasan Emosional.......

Eka Fajar Rahmani

Halaman 135-149

peneliti berharap mahasiswa tidak hanya meningkatkan kemampuan menulis akademik saja, tetapi juga mengembangkan kecerdasan emosional yang merupakan aspek prioritas. Setelah melakukan studi literatur, peneliti menemukan bahwa belum ada penelitian serupa yang menggabungkan konsep teknik $\mathrm{CW}$ terhadap perkembangan kecerdasan emosional peserta didik. Penelitian-penelitian yang dilakukan sebelumnya hanya membahas teknik $\mathrm{CW}$ dan kecerdasan emosional secara terpisah. Hal tersebut menjadi gap yang ingin peneliti jembatani. Oleh karenanya, berdasarkan permasalahan yang telah diuraikan, tujuan penelitian adalah untuk mengetahui apakah penerapan teknik $\mathrm{CW}$ dapat mengembangkan kecerdasan emosional Bahasa Inggris Sekolah Tinggi Bahasa Asing Pontianak, khususnya yang mengambil kelas Essay Writing dan Literary Criticism.

\section{METODE}

Penelitian menggunakan metode deskriptif kuantitatif. Subjek penelitian adalah mahasiswa Sekolah Tinggi Bahasa Asing Pontianak pada kelas Essay Writing dan Literary Criticism berjumlah 43 orang yang dipilih dengan teknik purposive sampling. Pemilihan subjek penelitian yaitu dengan pertimbangan bahwa subjek penelitian berpengetahuan dan berpengalaman dengan fokus penelitian. Penelitian dilakukan selama 3 kali pertemuan dengan tujuan untuk mendapatkan hasil yang valid. Alat pengumpul data menggunakan kuesioner dengan bentuk close-questionnaire yang telah divalidasi. Butir pernyataan berjumlah 21 buah yang mengacu pada 5 domain kecerdasan emosional yang diadaptasi dari Goleman (1996) dan Serrat (2017), mencakup self-awareness 3 pernyataan, self-regulation 5 pernyataan, self-motivation 4 pernyataan, social awareness 4 pernyataan, dan social skills 5 pernyataan.

Jumlah butir pernyataan pada setiap aspek kecerdasan emosional merupakan atribut atau karakteristik yang menjelaskan secara spesifik aspek tersebut. Lebih detail, pada aspek self-awareness terdapat 3 atribut, yaitu emotional awareness, accurate self-assessment, dan self-confidence. Pada aspek self-regulation terdapat 5 atribut, yaitu self-control, trustworthiness, conscientiousness, adaptability, dan innovativeness. Pada aspek self-motivation terdapat 4 atribut, yaitu empathy, 
service orientation, developing others, dan leveraging diversity. Kemudian, pada aspek social skills terdapat 8 atribut, yaitu influence, communication, leadership, change catalyst, conflict management, building bonds, collaboration and cooperation, dan capabilities.

Secara prosedural, penelitian dilakukan melalui tiga tahapan. Tahapan pertama yaitu peneliti menyiapkan kelengkapan penelitian yang mencakup kajian literatur, perumusan butir kuesioner, dan pemilihan topik yang akan dibahas serta aktivitas kelas menggunakan teknik CW pada setiap pertemuan penelitian. Pada tahapan pertama, peneliti melakukan validasi dan penghitungan reliabilitas dari kuesioner sebelum didistribusikan ke subjek penelitian. Validasi yang dilakukan adalah validasi konten (content validity) yang dihitung dengan menguji kelayakan atau relevansi tiap butir kuesioner melalui expert judgement terhadap teori atau konsep yang digunakan menggunakan pendekatan Content Validity Index (CVI) (Hendryadi, 2017). Kuesioner didistribusikan kepada 3 orang ahli dengan menggunakan respons 1 dan 0 . Nilai validasi dirujuk dengan menghitung nilai ratarata I-CVI dan membandingkannya dengan proporsi rata-rata butir pada masingmasing ahli. Nilai rujukan untuk validasi adalah antara 0,78-1,00 seperti yang disarankan oleh Lynn (Hendryadi, 2017). Sedangkan untuk reliabilitas kuesioner, peneliti menggunakan uji reliabilitas Cronbach's Alpha dengan Rumus KR-21 yang dapat dilihat pada rumus (1) (Putri \& Hidayat, 2013).

$$
r_{11}=\left[\frac{k}{k-1}\right]\left[1-\frac{\sum \sigma^{2} b}{\sigma^{2} t}\right]
$$

Keterangan: $\mathrm{r}_{11}$ adalah koefisien reliabilitas alpha; $\mathrm{k}$ adalah jumlah item pertanyaan; $\Sigma \sigma^{2} \mathrm{~b}$ adalah jumlah varian butir; $\sigma^{2} \mathrm{t}$ adalah varians total.

Nilai rujukan reliabilitas adalah menggunakan skala koefisien 0,0-1,0 seperti yang terlihat pada Tabel 1 .

Tabel 1 Skala Koefisien Reliabilitas

\begin{tabular}{cc}
\hline Nilai Koefisien & Kategori \\
\hline $\mathrm{r}_{11}<0,20$ & Sangat Rendah \\
$0,20 \leq \mathrm{r}_{11} \geq 0,40$ & Rendah \\
$0,40 \leq \mathrm{r}_{11} \geq 0,70$ & Sedang \\
$0,70 \leq \mathrm{r}_{11} \geq 0,90$ & Tinggi \\
$0,90 \leq \mathrm{r}_{11} \geq 1,00$ & Sangat Tinggi \\
\hline
\end{tabular}


Edukasi: Jurnal Pendidikan, Volume 19 Nomor 1 Tahun 2021

Persepsi Mahasiswa terhadap Kecerdasan Emosional.......

Eka Fajar Rahmani

Halaman 135-149

Tahapan yang kedua yaitu pengimplementasian teknik CW yang diterapkan sebanyak 3 kali pada setiap kelas. Subjek penelitian diberikan topik yang berbeda pada setiap pertemuan dan juga bekerja pada anggota kelompok yang berbedabeda dengan tujuan mendapatkan pengalaman yang bervariasi; sedangkan untuk prosedur penerapan teknik $\mathrm{CW}$ relatif sama. Pada setiap akhir pertemuan, kuesioner didistribusikan sehingga subjek penelitian dapat langsung memberikan respons setelah teknik CW selesai diimplementasikan. Kuesioner yang diberikan akan menunjukkan respons mahasiswa apakah terjadi peningkatan respons pada aspek kecerdasan emosional dan seberapa tinggi peningkatan tersebut.

Tahapan yang terakhir yaitu analisis data. Peneliti menganalisis kuesioner yang telah direspons oleh subjek penelitian. Teknik analisis data yang digunakan adalah kalkulasi atau perhitungan persentase pada setiap butir kuesioner yang merupakan atribut dari aspek kecerdasan emosional. Selanjutnya, peneliti menginterpretasi, mendeskripsi, dan menarasi hasil kuesioner yang telah dianalisis.

\section{HASIL DAN PEMBAHASAN}

Hasil uji validasi kuesioner sebagai instrumen data penelitian menunjukkan bahwa tiap butir kuesioner yang digunakan valid dengan nilai rujukan rata-rata 0,90 (I-CVI mean score) yang sebanding dengan Proporsi Relevan pada ketiga ahli dengan nilai 0,$86 ; 0,85$; dan 1,00 secara berurutan. Sedangkan dari hasil perhitungan reliabilitas dapat diinterpretasikan bahwa kuesioner dengan jumlah 21 butir pernyataan masuk dalam kategori "Tinggi" dengan nilai $r_{11}=0,87$ yang berada pada rentang $0,70 \leq \mathrm{r}_{11} \geq 0,90$. Hasil tersebut menunjukkan bahwa kuesioner layak digunakan dan didistribusikan kepada subjek penelitian.

Berdasarkan hasil analisis data kuesioner yang telah dikumpulkan didapatkan gambaran bahwa secara keseluruhan terjadi peningkatan kecerdasan emosional pada mahasiswa setelah teknik CW diterapkan. Peningkatan tersebut didapatkan berdasarkan persepsi dari subjek penelitian dimana teknik CW diterapkan. Perkembangan aspek kecerdasan emosional diindikasikan dengan peningkatan atribut-atribut pada setiap aspek yang dinilai. 


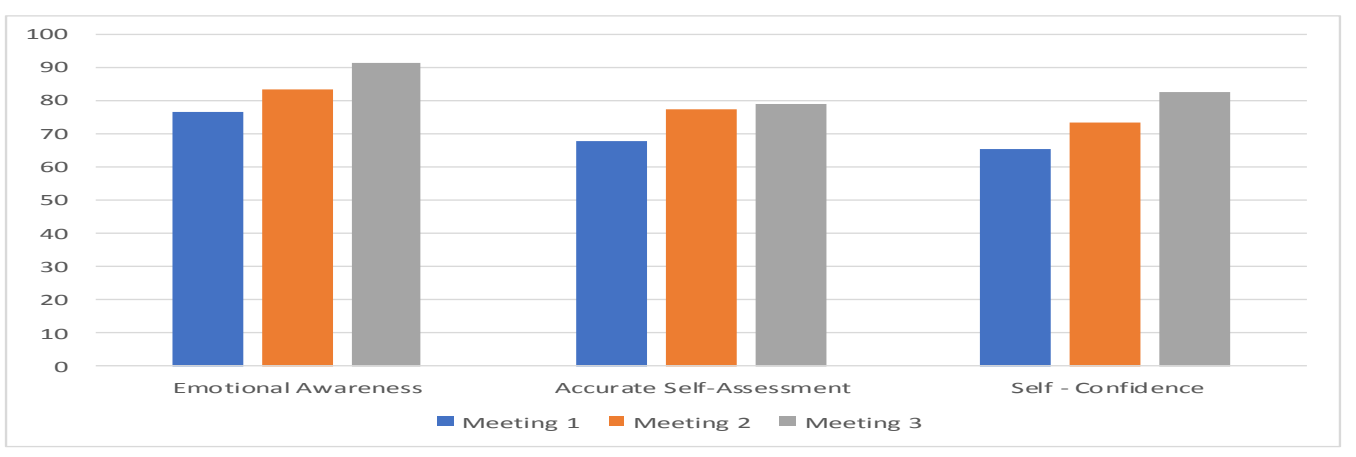

Gambar 1 Self-Awareness Aspect

Gambar 1 menunjukkan adanya peningkatan pada ketiga atribut selfawareness aspect dari pertemuan 1 sampai pertemuan 3. Dapat dilihat bahwa pada atribut emotional awareness terjadi peningkatan sebesar $14,3 \%$ dari $76,7 \%$ pada pertemuan 1 menjadi 91,3\% pada pertemuan 3. Sedangkan, pada atribut accurate self-assessment, terjadi peningkatan sebesar 11,3\% dari 67,8\% pada pertemuan 1 menjadi $79,1 \%$ pada pertemuan 3. Kemudian, pada atribut self-confidence terjadi peningkatan sebesar $17,1 \%$ dari $65,5 \%$ pada pertemuan 1 menjadi $82,6 \%$ pada pertemuan 3. Sehingga dapat disimpulkan bahwa pada self-awareness aspect, atribut emotional awareness mendapatkan respons paling banyak dan atribut selfconfidence berkembang cukup signifikan dibandingkan dengan 2 atribut lainnya.

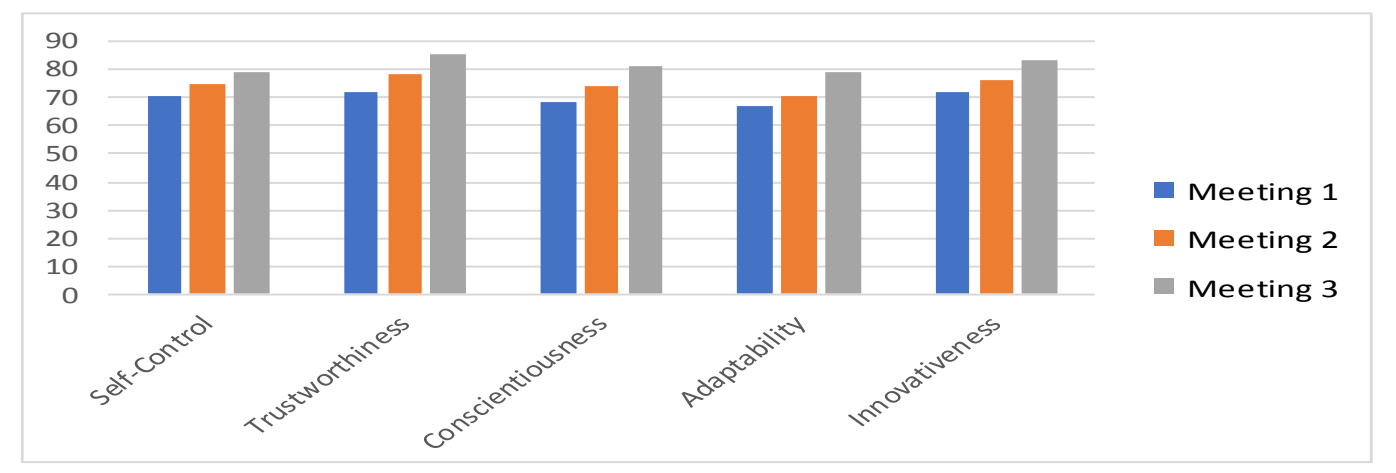

Gambar 2 Self-Regulation Aspect

Gambar 2 menunjukkan aspek self-regulation. Kesemua atribut yang dinilai mengalami peningkatan dari pertemuan 1 hingga pertemuan 3. Atribut self-control meningkat sebesar $8,3 \%$ dari $70,7 \%$ pada pertemuan 1 menjadi $79 \%$ pada pertemuan 3. Atribut trustworthiness meningkat sebesar $13 \%$ dari $72,3 \%$ pada pertemuan 1 menjadi $85,3 \%$ pada pertemuan 3. Selanjutnya, conscientiousness meningkat sebesar $12,7 \%$ dari $68,5 \%$ pada pertemuan 1 menjadi $81,2 \%$ pada 
Edukasi: Jurnal Pendidikan, Volume 19 Nomor 1 Tahun 2021

Persepsi Mahasiswa terhadap Kecerdasan Emosional.......

Eka Fajar Rahmani

Halaman 135-149

pertemuan 3. Selanjutnya, atribut adaptability meningkat sebesar $12,6 \%$ dari $66,7 \%$ pada pertemuan 1 menjadi $79,3 \%$ pada pertemuan 3 . Terakhir, atribut innovativeness mengalami peningkatan sebesar $13,8 \%$ dari $72,2 \%$ pada pertemuan 1 menjadi $83,3 \%$ pada pertemuan 3. Berdasarkan hasil tersebut, dapat dilihat bahwa atribut yang berkembang secara signifikan adalah trustworthiness.

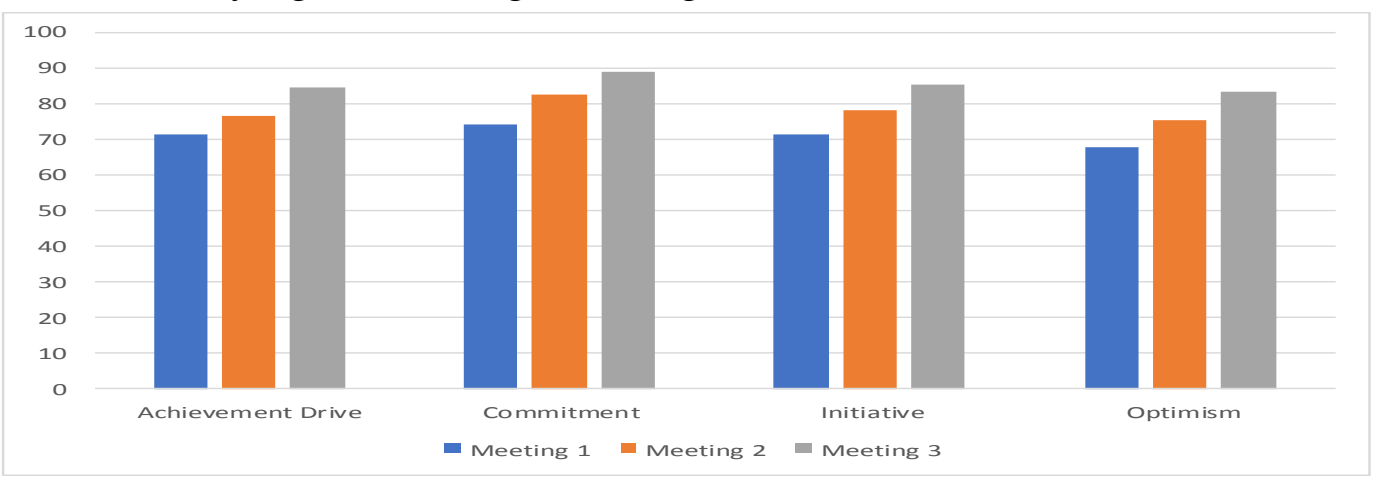

Gambar 3 Self-Motivation Aspect

Gambar 3 menunjukkan keempat atribut yang dinilai meningkat dari pertemuan 1 sampai pertemuan 3. Atribut achievement drive meningkat sebesar $12,6 \%$ dari $71,4 \%$ pada pertemuan 1 menjadi $84,5 \%$ pada pertemuan 3 . Atribut commitment meningkat sebesar $14,6 \%$ dari $74,4 \%$ pada pertemuan 1 menjadi $89 \%$ pada pertemuan 3. Atribut initiative meningkat sebesar $14 \%$ dari $71,3 \%$ pada pertemuan 1 menjadi $85,3 \%$ pada pertemuan 3. Selanjutnya, atribut optimism meningkat sebesar $15,9 \%$ dari $67,7 \%$ pada pertemuan 1 menjadi $83,6 \%$ pada pertemuan 3. Dari hasil tersebut dapat dilihat bahwa pada aspek self-motivation atribut yang berkembang secara signifikan adalah optimism sebesar 15,9\% dan commitment sebesar $14,6 \%$.

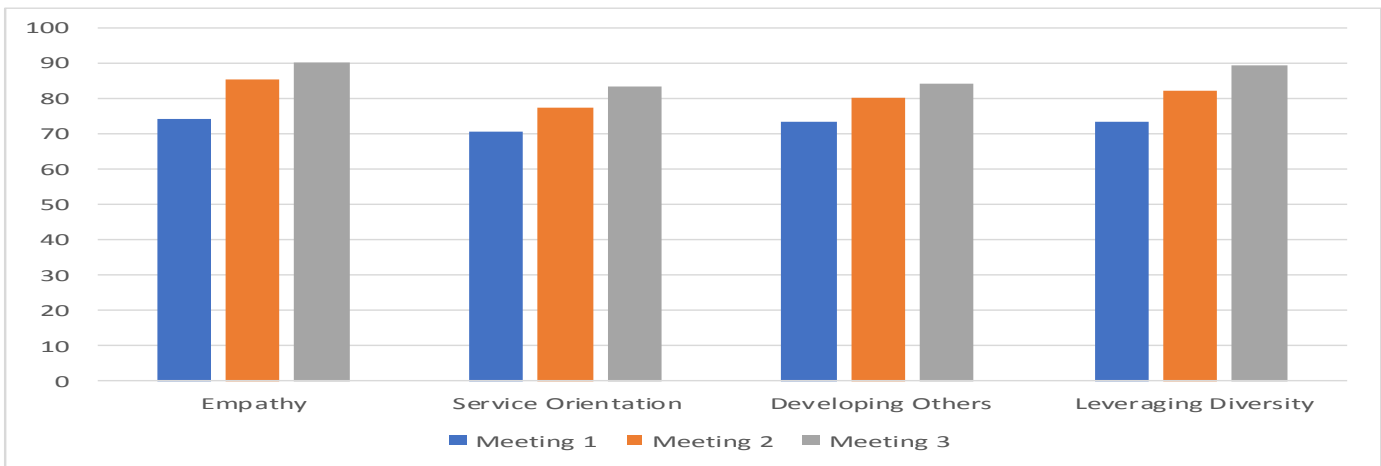

Gambar 4 Social Awareness Aspect 
Gambar 4 menunjukkan bahwa keempat atribut pada social-awareness mengalami peningkatan dari pertemuan 1 sampai pertemuan 3. Atribut empathy meningkat sebesar $16,1 \%$ dari $74,2 \%$ pada pertemuan menjadi $90,3 \%$ pada pertemuan 3. Atribut service orientation meningkat sebesar $12,9 \%$ dari $70,5 \%$ pada pertemuan 1 menjadi $83,4 \%$ pada pertemuan 3. Atibut developing others meningkat sebesar $11 \%$ dari $73,3 \%$ menjadi $84,3 \%$ pada pertemuan 3 . Terkahir, atribut leveraging diversity meningkat sebesar $15,7 \%$ dari $73,6 \%$ pada pertemuan 1 menjadi 89,3\% pada pertemuan 3. Dari hasil analisis tersebut, dapat dilihat atribut yang secara signifikan berkembang pada aspek social awareness adalah empathy diikuti leveraging diversity dan service orientation.

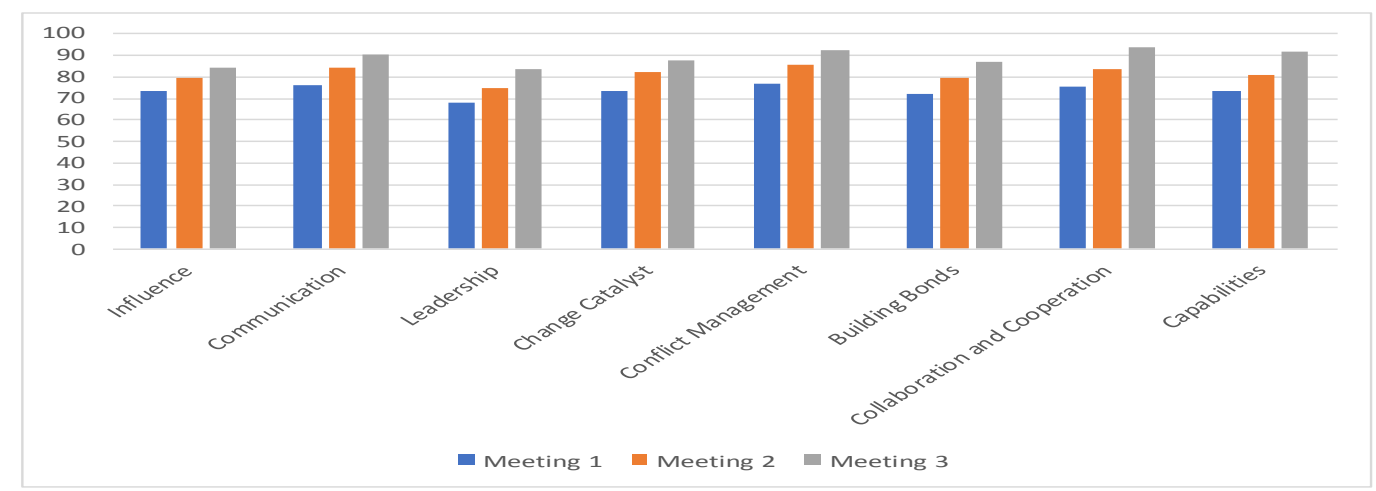

Gambar 5 Social Skill Aspect

Gambar 5 menunjukkan bahwa kedelapan atribut pada aspek social skill mengalami peningkatan dari pertemuan 1 hingga pertemuan 3. Atribut influence meningkat sebesar $11 \%$ dari $73,4 \%$ pada pertemuan 1 menjadi $84,4 \%$ pada pertemuan 3. Atribut communication meningkat sebesar 13,8\% dari 76,3\% pada pertemuan 1 menjadi $90,1 \%$ pada pertemuan 3. Atribut leadership meningkat sebesar $19,3 \%$ dari $67,7 \%$ pada pertemuan 1 menjadi $83,4 \%$ pada pertemuan 3 . Atribut change catalyst meningkat sebesar $14 \%$ dari $73,5 \%$ pada pertemuan 1 menjadi $87,5 \%$ pada pertemuan 3 . Selanjutnya, conflict management meningkat sebesar $15,8 \%$ dari $76,5 \%$ pada pertemuan 1 menjadi $92,3 \%$ pada pertemuan 3 . Atribut building bonds meningkat sebesar $14,2 \%$ dari $72,5 \%$ pada pertemuan 1 menjadi $86,7 \%$ pada pertemuan 3. Atribut collaboration and cooperation meningkat sebesar $18,2 \%$ dari $75,5 \%$ pada pertemuan 1 menjadi $93,7 \%$ pada pertemuan 3. Terakhir, atribut capabilities meningkat sebesar $18,2 \%$ dari $73,4 \%$ 
Edukasi: Jurnal Pendidikan, Volume 19 Nomor 1 Tahun 2021

Persepsi Mahasiswa terhadap Kecerdasan Emosional.......

Eka Fajar Rahmani

Halaman 135-149

pada pertemuan 1 menjadi 91,6\% pada pertemuan 3. Dari hasil tersebut dapat dilihat bahwa atribut yang meningkat secara signifikan adalah leadership, collaboration and cooperation, dan capabilities.

Hasil analisis data penelitian secara garis besar menunjukkan bahwa kecerdasan emosional dapat ditingkatkan dengan menerapkan pembelajaran kolaboratif, khususnya teknik CW. Kelima aspek kecerdasan emosional yang ditanyakan, tidak ada satupun yang mengalami penurunan respons selama 3 penerapan teknik CW. Hal tersebut berarti bahwa subjek penelitian menerima dan merasakan manfaat teknik CW terhadap peningkatan aspek-aspek kecerdasan emosional. Lebih detail, dari 21 atribut aspek kecerdasan emosional, didapatkan 11 atribut yang berkembang secara signifikan. Atribut-atribut tersebut yaitu selfconfidence dan emotional awareness pada aspek self-awareness; trustworthiness pada aspek self-regulation; optimism dan commitment pada aspek self-motivation; empathy, leveraging diversity, dan service orientation pada aspek social awareness; serta leadership, collaboration and cooperation, dan capabilities pada aspek social skill. Keberhasilan penerapan teknik CW dalam mengembangkan kecerdasan emosional mahasiswa tidak lepas dari prinsip pembelajaran kolaboratif yang telah terbukti sangat efektif meningkatkan kecerdasan emosional.

Pentingnya kecerdasan emosional telah banyak ditegaskan dalam studi dimana kecerdasan kognitif (seperti intelligence quotient atau IQ) untuk era sekarang tidak lagi menjadi faktor penentu kesuksesan seseorang melainkan kecerdasan emosional (Serrat, 2017; Emmanuel et al., 2016; Romero-Ternero, 2013; Yahaya et al., 2012). Cognitive variable seperti kemampuan kompetensi dan keterampilan sebenarnya tidak secara mandiri menghasilkan kesuksesan. Faktor non-IQ, seperti kecerdasan emosional yang sebenarnya memerankan peran yang lebih banyak sebagai sebuah metaability yang mendorong perkembangan serangkaian faktor penentu, seperti motivation, impulse control, mood regulation, dan empathy yang menentukan seberapa baik seseorang menggunakan kemampuan kognitif untuk menjadi sukses (Ghufron, 2016; Kadeni, 2014; Masruroh, 2014; Yenti et al., 2014; Romero-Ternero, 2013). 
Secara spesifik, kecerdasan emosional sangat penting untuk bidang pendidikan, khususnya pendidikan tinggi seperti universitas karena mahasiswa akan terjun ke dunia pekerjaan setelah selesai studi (Mandala \& Dihan, 2018; Putri, 2016). Kecerdasan emosional membentuk karakter positif seperti kepribadian yang baik, ulet, dan optimis (Atika \& Kamaruzzaman, 2015; Rustam, 2014). Dengan mengembangkan kecerdasan emosional, mahasiswa akan mampu menjadi lebih produktif dan berhasil atas apa yang dikerjakan, serta juga dapat membantu orang lain untuk menjadi produktif dan sukses (Sukmawati \& Rustam, 2019; Serrat, 2017). Perlu adanya dukungan dari dosen sebagai pendidik untuk membantu mahasiswa mengembangkan kecerdasan emosional, satu diantaranya dengan menerapkan teknik pembelajaran kolaboratif, khususnya teknik CW.

\section{SIMPULAN}

Hasil analisis data menunjukkan bahwa kecerdasan emosional subjek penelitian yang mencakup self-awareness, self-regulation, self-motivation, social awareness, dan social skills mengalami perkembangan signifikan berdasarkan respons positif yang diberikan subjek penelitian terhadap tiap butir atribut aspek kecerdasan emosional. Berdasarkan hasil tersebut, disimpulkan bahwa teknik collaborative writing dapat digunakan untuk meningkatkan kecerdasan emosional mahasiswa Sekolah Tinggi Bahasa Asing yang mengambil mata kuliah Literary Criticism dan Essay Writing.

\section{DAFTAR PUSTAKA}

Atika, A., \& Kamaruzzaman. (2015). Upaya meningkatkan kecerdasan emosional melalui peer counseling pada siswa kelas X SMA Negeri 10 Pontianak. Sosial Horizon: Jurnal Pendidikan Sosial, 2(2), 121-130. http://dx.doi.org/ 10.31571/sosial.v2i2.99.

Bol, L., \& Hacker, D. J. (2012). Calibration in N seel (Ed.), Encyclopedia of the Sciences of Learning. United States of America: Springer Science+Business Media. https://doi.org/10.1007/978-1-4419-1428-6.

Deveci, T. (2018). Student perceptions on collaborative writing in a project-based 
Edukasi: Jurnal Pendidikan, Volume 19 Nomor 1 Tahun 2021

Persepsi Mahasiswa terhadap Kecerdasan Emosional.......

Eka Fajar Rahmani

Halaman 135-149

course. Universal Journal of Educational Research, 6(4), 721-732. https://doi.org/10.13189/ujer.2018.060415.

Emmanuel, D. O. O., Onyinye, O. R., \& Chimezie, D. N. M. (2016). Competence among accounting students. Competence Among Accounting Undergraduates in South-East, 4(2), 1-12.

Fong, L. S. (2012). Benefits of collaborative writing for ESL advanced diploma students in the production of reports, 4(4), 396-407.

Goleman, D. (1996). Emotional intelligence: Why it can matter more than IQ. Great Britain: Bloomsbury Publishing.

Ghufron, M. N. (2016). Peran kecerdasan emosi dalam meningkatkan toleransi beragama. Fikrah: Jurnal Ilmu Aqidah dan Studi Keagamaan, 4(1), 138153. http://dx.doi.org/10.21043/fikrah.v4i1.1664.

Hendryadi, H. (2017). Validitas isi: Tahap awal pengembangan kuesioner. Jurnal Riset Manajemen dan Bisnis (JRMB) Fakultas Ekonomi UNIAT, 2(2), 169178. https://doi.org/10.36226/jrmb.v2i2.47.

Husain, R. (2013). Pengembangan model pembelajaran kolaboratif dalam meningkatkan hasil belajar warga belajar Paket C (Studi di SKB Kota Gorontalo). Journal of Chemical Information and Modeling, 53(9), 16891699.

Ibrahim, N., Shak, M. S. Y., Mohammad, T., Ismail, N. A., Perumal, P. D., Zaidi, A., \& Yasin, S. M. A. (2015). The importance of implementing collaborative learning in the English as a second language (ESL) classroom in Malaysia. Procedia Economics and Finance, 31(15), 346-353. https://doi.org/10.1016/s2212-5671(15)01208-3.

Junus, F., \& Andula, N. (2020). Pengaruh implementasi moodle dan model pembelajaran kolaboratif pada lingkungan blended learning terhadap peningkatan pemahaman belajar mahasiswa. Jurnal Teknologi Informasi dan Ilmu Komputer, 7(4), 797-806. http://dx.doi.org/10.25126/jtiik. 2020743289.

Kadeni. (2014). Pentingnya kecerdasan emosional dalam pembelajaran. Equilibrium: Jurnal Ilmiah Ekonomi dan Pembelajarannya, 2(1), 1-14. 
http://doi.org/10.25273/equilibrium.v2i1.601.

Le, H., Janssen, J., \& Wubbels, T. (2018). Collaborative learning practices: teacher and student perceived obstacles to effective student collaboration. Cambridge Journal of Education, 48(1), 103-122. https://doi.org/10.1080/ 0305764X.2016.1259389.

Luy-Montejo, C. (2019). Problem based learning (PBL) in the Development of emotional intelligence of university students. Journal of Educational Psychology - Propositos y Representaciones, 7(2), 369-383.

Mandala, E., \& Dihan, F. (2018). pengaruh kecerdasan emosional dan kecerdasan spiritual pada kepuasan kerja yang berdampak terhadap kinerja karyawan PT. Madu Baru Bantul, Yogyakarta. Kajian Bisnis Sekolah Tinggi Ilmu Ekonomi Widya Wiwaha,26(1), 13-29. https://doi.org/10.32477/jkb. v26i1.127.

Masruroh, A. (2014). Konsep kecerdasan emosional dalam perspektif pendidikan Islam. MUDARRISA: Jurnal Kajian Pendidikan Islam, 6(1), 61-87. https://doi.org/10.18326/mdr.v6i1.61-87.

Nisa, H., Disman, D., \& Dahlan, D. (2018). Pengaruh penerapan model pembelajaran kolaboratif teknik group investigation terhadap kemampuan berpikir analisis peserta didik. Manajerial: Jurnal Manajemen dan Sistem Informasi, 17(2), 157-166. https://doi.org/10.17509/manajerial.v17i2.10277.

Putri, P. P., \& Hidayat, H. (2013). Hubungan antara pemanfaatan bahan pustaka perpustakaan sekolah dengan minat belajar siswa. Edulib, 1(1), 38-47. https://doi.org/https://doi.org/10.17509/edulib.v3i1.4147.

Putri, Y. S. (2016). Pengaruh kecerdasan intelektual, kecerdasan emosional, dan lingkungan kerja terhadap kinerja karyawan PT. PLN Persero area Klaten. Jurnal Studi Manajemen Organisasi, 13(1), 88-97. https://doi.org/10.14710/ jsmo.v13i1.13416.

Rahayu, E. S. (2016). Using Google Docs on collaborative writing technique for teaching English to non English department students. Proceedings of ISELT FBS Universitas Negeri Padang, 4(1), 226-236.

Romero-Ternero, M. C. (2013). Can cooperative learning promote emotional 
Edukasi: Jurnal Pendidikan, Volume 19 Nomor 1 Tahun 2021

Persepsi Mahasiswa terhadap Kecerdasan Emosional.......

Eka Fajar Rahmani

Halaman 135-149

intelligence in our students? Academic and professional achievement. $7^{\text {th }}$ IEEE International Conference on E-Learning in Industrial Electronics (ICELIE), 7(2013), 60-65.

Rustam. (2014). Pengembangan model bimbingan kelompok berbasis islami untuk meningkatkan kecerdasan emosional siswa. Sosial Horizon: Jurnal Pendidikan Sosial, 1(1), 83-94. http://dx.doi.org/10.31571/sosial.v1i1.150.

Serrat, O. (2017). Understanding and developing emotional intelligence. In knowledge solutions: Tools, methods, and approaches to drive organizational performance. Singapore: Springer. https://doi.org/10.1007/ 978-981-10-0983-9.

Sunita, W., Parmithi, N., \& Yanti, N. P. W. R. (2020). Pengaruh model pembelajaran kolaboratif dan motivasi belajar terhadap hasil belajar Matematika peserta didik kelas X IPS SMA Negeri 1 Abiansemal. Emasains: Jurnal Edukasi Matematika dan Sains, 9(1), 45-55. https://doi.org/10.5281/zenodo.3743189.

Talib, T., \& Cheung, Y. L. (2017). Collaborative writing in classroom instruction: A synthesis of recent research. The English Teacher, 46(2), 43-57.

Wicaksono, S. R. (2013). Implementation of collaborative learning in higher education environment. Journal of Education and Learning (EduLearn), 7(4), 219. https://doi.org/10.11591/edulearn.v7i4.196.

Yahaya, A., Ee, N. S., Bachok, J., Yahaya, N., Boon, Y., Hashim, S., \& Lee, G. M. (2012). The impact of emotional intelligence element on academic achievement. Archives Des Sciences, 65(4), 2-16.

Yenti, N., Machasin, \& Amsal, C. (2014). Pengaruh kecerdasan emosional, kecerdasan intelektual, dan disiplin terhadap kinerja perawat pada RS PMC Pekanbaru. Jurnal Online Mahasiswa Fakultas Ekonomi, 1(2), 1-21.

Zhang, M. (2018). Collaborative writing in the EFL classroom: The effects of L1 and L2 use. System, 76(4), 1-12. https://doi.org/10.1016/j.system. 2018.04.009. 